\title{
DRUGS AND DEVICES IN PREVENTION AND TREATMENT OF CHEMOTHERAPY-INDUCED ALOPECIA: WHEN AND HOW SHOULD BE EMPLOYED
}

\author{
CARO G, ROSSI A., FORTUNA MC., PIGLIACELLI F., D'ARINO A., CARLESIMO M.
}

\section{BACKGROUND}

Incidence of chemotherapy-induced alopecia (CIA): 65\% [1].

Different shedding patterns:

- mild-moderate damage $\rightarrow$ telogen effluvium

- severe damage $\rightarrow$ dystrophic anagen effluvium
Classical anticancer drugs are cytotoxic

- Main target $\rightarrow$ rapidly proliferating cells (hair follicle matrix keratinocytes in anagen phase; pigmentary system)

- Protect from chemotherapy toxicity $\rightarrow$ Catagen and telogen phases (lower mitotic rate)

No guidelines available for prevention and treatment

Our aim: analyze drugs and devices proposed in li terature; giving our evidenced based opinion

\section{SCALP COOLING}

How: Local vasoconstriction and reduction of drug inflow to the hair

follicles (by cold)

Reported results: CIA prevention rates 50-80\%

Approved: yes no

Compliance: high nlow

Side effects: headache, discomfort, nausea and xerosis

Limitation: action limited to the application time not prevention of toxic effects occurring during the weeks from an infusion to another Unreccomandations: platinum derivatives (limited tolerance to cold) hematological tumors (risk of scalp metastasis); concomitant cold agglutinin disease, cryoglobulinemia, and posttraumatic cold injury. [2]

\section{TOPICAL MINOXIDIL 2\% AND 5\%}

How:

- Vasodilatation (by action on peripheral arteria) $\rightarrow$ slowing down of circulation $\rightarrow$ greater permanence of the anticancer drug around the hair follicle

- Induction of angiogenesis (upregulating VEGF)

- Activation of prostaglandin-endoperoxidase syntetasis $1 \rightarrow$ hair growth stimulation [4].

Final effect $\rightarrow$ shorten telogen phase and extend anagen phase Reported results: CIA development in 88\% (minoxidil 2\%) and 92\% (minoxidil5\%); shortening the period of baldness

Approved:

Compliance: high 口low

Side effects: scalp pruritus, scalp folliculitis, facial hair growth Our opinion: not recommended for CIA prevention (clinical inefficacy lack of a scientific rational)

\section{TOPICAL VASOCONSTRICTORS EPINEPHRINE AND NOREPINEPHRINE}

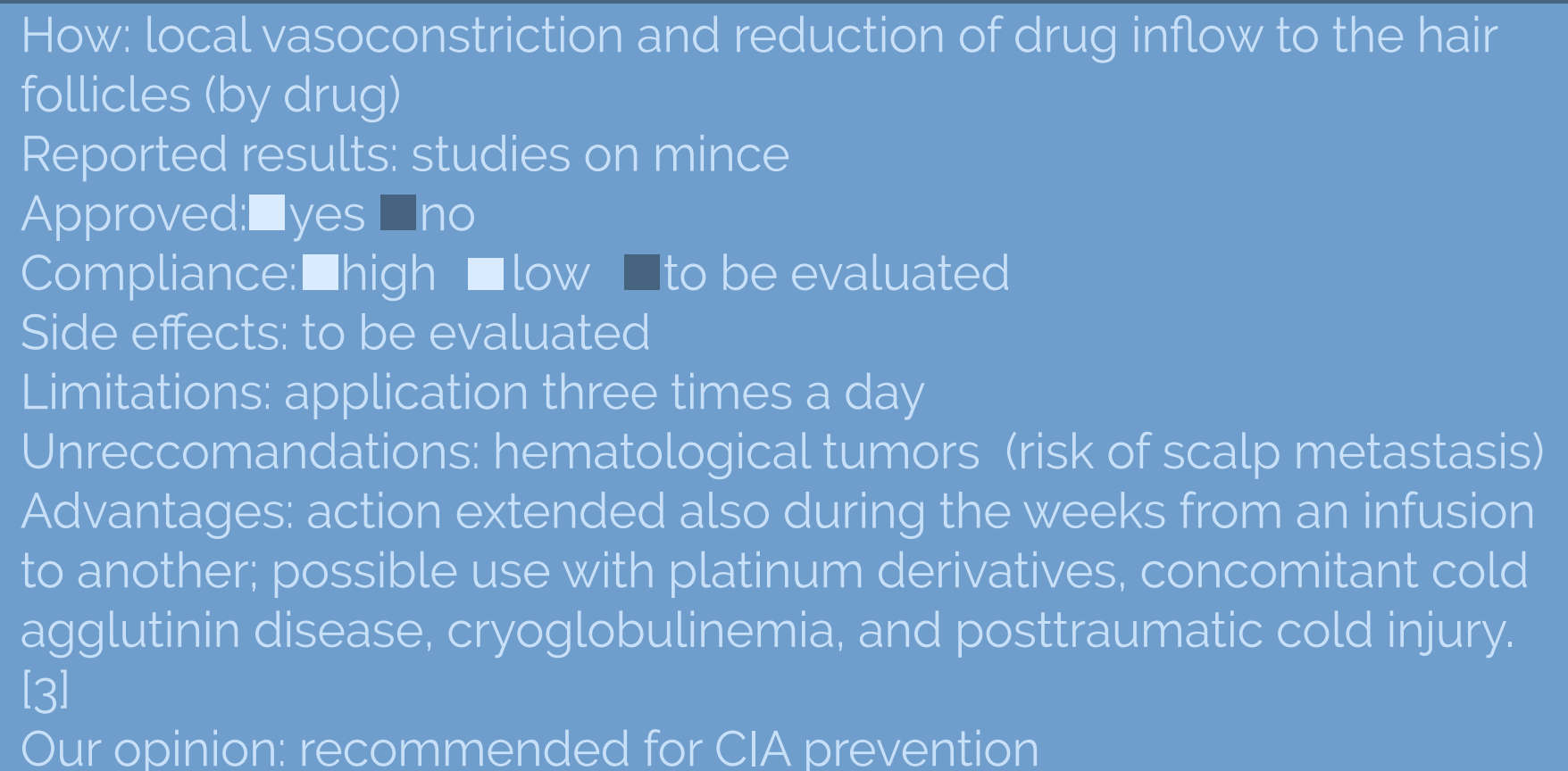

\section{TOPICAL BIMATOPROST $0.03 \%$}

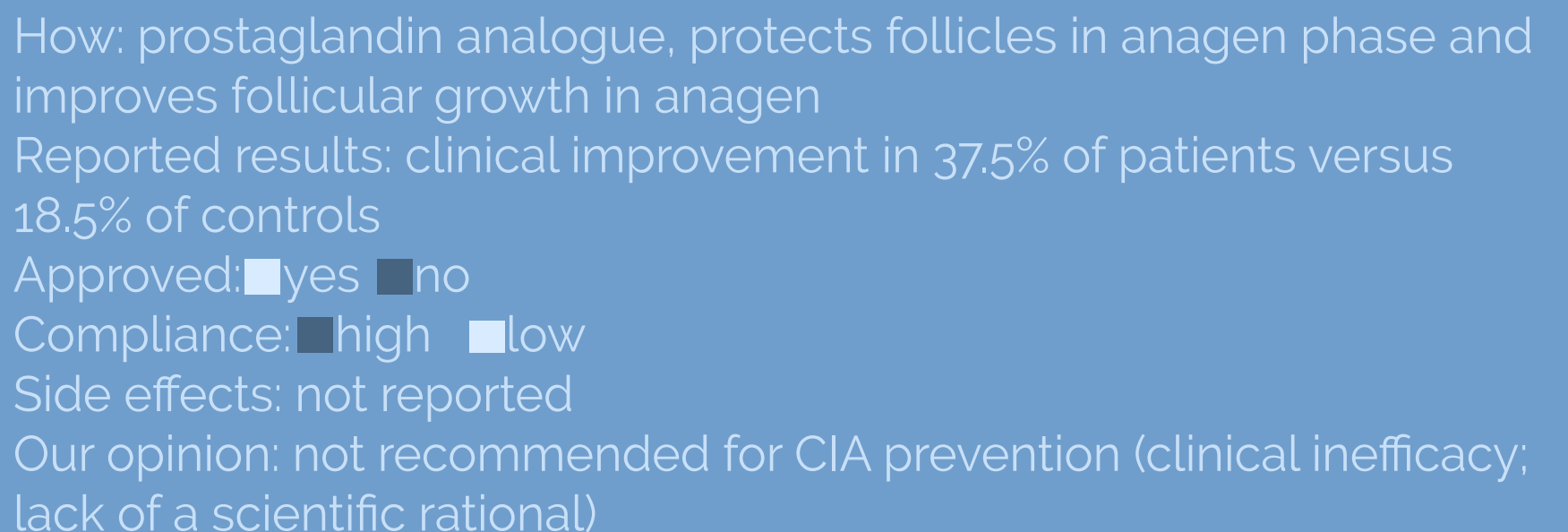
lack of a scientific rational)

\section{7}

$\Rightarrow$ We suggest: use after chemotherapy discontinuation for a greater regrowth (better moment for introduction evaluated considering chemotherapic drugs half-life and monitoring scalp with trichoscopy and trichogram [3])

\section{CONCLUSIONS AND PRACTICAL ADVICE}

\section{Excluding scalp cooling, we actually have no effective drugs for CIA prevention.}

Trichoscopy and trichogram could drive the treatment.

- Numerous black dots and flame hair: index of an acute and severe insult $\rightarrow$ Use scalp cooling or topical vasoconstrictors

- Pohl pinkus: mitotic activity is not completely interrupted $\rightarrow$ Use scalp cooling or topical vasoconstrictors when insult is higher

- Numerous yellow dots: follicle are protected by acute damage. Delayed hypoxic insult could induce neogenesis of Hair Follicle Stam Cells (HFSC) $\rightarrow$ indiscriminate use of scalp cooling and vasoconstrictors could be harmful if other chemotherapy cycles are expected

1. ROSSI A, CATERINA FORTUNA M, CARO G, CARDONE M, GARELLIV, GRASSI S, CARLESIMO M. MONITORING CHEMOTHERAPY-INDUCED ALOPECIA WITH TRICHOSCOPY. J COSMET DERMATOL. 2018 JUL 11

2. REED WPM, VAN DEN HURK CJG, PEERBOOMS M. PRESENTATION, IMPACT AND PREVENTION OF CHEMOTHERAPY-INDUCED HAIR LOSS: SCALP COOLING POTENTIALS AND LIMITATIONS. EXPERT REVIEW OF DERMATOLOGY. 2011;6(1):109-125

3. SOREF CM, FAHL WE. A NEW STRATEGY TO PREVENT CHEMOTHERAPY AND RADIOTHERAPY-INDUCED ALOPECIA USING TOPICALLY APPLIED VASOCONSTRICTOR. INT J CANCER. 2015:136(1):195-203

4. ROSSI A, ANZALONE A, FORTUNA MC, CARO G, GARELLIV, PRANTEDA G, CARLESIMO M. MULTI-THERAPIES IN ANDROGENETIC ALOPECIA: REVIEW AND CLINICAL EXPERIENCES. DERMATOL THER. 2016 NOV:29(6):424-432. EPUB $2016 \mathrm{JUL} 18$ 